OPEN ACCESS

Indonesian Journal of Human Nutrition
P.ISN 2422-636
EISSN 24355-3987
www.jijnn.ub.ac.id

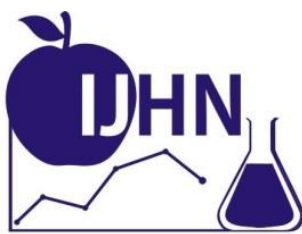

Artikel Hasil Penelitian

\title{
Status Gizi sebagai Prediktor Kualitas Hidup Pasien Kanker Kepala dan Leher
}

\section{(Nutritional Status as Predictor of Life Quality in Patient with Neck and Head Cancer)}

\author{
Fuadiyah Nila Kurniasari $^{1}{ }^{*}$, Agus Surono $^{2}$ dan Retno Pangastuti ${ }^{3}$ \\ ${ }^{1}$ Jurusan Gizi Fakultas Kedokteran Universitas Brawijaya \\ ${ }^{2}$ SMF THT RSUP dr. Sardjito Yogyakarta \\ ${ }^{3}$ Instalasi Gizi RSUP dr. Sardjito Yogyakarta \\ * Alamat korespondensi, E-Mail: fuadiyahnila@gmail.com; Telp/Fax : (0341) 567192 / \\ (0341) 564755
}

Diterima: / Direview: /Dimuat: April 2015 / Mei 2015 / Juni 2015

\begin{abstract}
Abstrak
Prevalensi kanker kepala leher (KKL) di Indonesia cukup tinggi dengan prevalensi 4,7 per 100.000 penduduk. Pasien kanker berisiko tinggi terhadap gizi kurang, dimana status gizi berpengaruh terhadap kualitas hidup dan perasaan nyaman pada pasien. Penelitian ini bertujuan untuk mengetahui berbagai indikator status gizi yang dapat digunakan untuk memprediksi kualitas hidup pasien KKL. Penelitian ini merupakan penelitian observasional dengan rancangan potong lintang yang dilakukan di RS Saiful Anwar Malang selama bulan Nopember 2010 - Januari 2011. Subjek yang diteliti adalah pasien KKL yang memenuhi kriteria inklusi sebanyak 45 subjek. Status gizi ditentukan melalui 3 metode, yaitu Indeks Massa Tubuh (IMT), Subjective Global Assessment (SGA), dan asupan makanan. Pengumpulan data dilakukan dengan cara wawancara dan pemeriksaan. Analisis bivariat menggunakan Chi Square dan multivariat menggunakan regresi linier ganda. Terdapat hubungan yang signifikan antara SGA kategori A $\left(\beta_{1}=30,631 ; p=0,001\right)$, asupan protein $\left(\beta_{2}=0,344 ; p=0,009\right)$, IMT $\left(\beta_{3}=-1,533\right.$; $\mathrm{p}=0,028)$, dan SGA kategori $\mathrm{B}\left(\beta_{4}=13,353 ; \mathrm{p}=0,039\right)$ dengan kualitas hidup pasien KKL dengan konstanta multivariat sebesar 47,086. Asupan energi terwakili oleh asupan protein, dimana hubungan keduanya adalah sinergis. Tidak terdapat hubungan antara asupan vitamin A dengan kualitas hidup $\left(\beta_{5}=0,000 ; \mathrm{p}=0,907\right)$. Sehingga status gizi dapat digunakan sebagai prediktor untuk menentukan skor kualitas hidup pasien KKL yaitu dengan formula: kualitas hidup pasien $\mathrm{KKL}=47,1+30,6($ jika SGA A) + 0,3 (asupan protein $(\mathrm{g}))-1,5\left(\mathrm{IMT}\left(\mathrm{kg} / \mathrm{m}^{2}\right)\right)+13,3($ jika SGA B). Status gizi yang dinilai dengan IMT, asupan protein, dan SGA dapat digunakan untuk memprediksi besarnya skor kualitas hidup pasien KKL, dimana SGA merupakan faktor yang paling berpengaruh dalam menentukan kualitas hidup pasien KKL.

Kata Kunci: indeks massa tubuh, asupan energi, protein, vitamin A, subjective global assessment ( $S G A)$, kualitas hidup, kanker kepala dan leher
\end{abstract}




\begin{abstract}
In Indonesia cancer is the seventh cause of mortality. The prevalence of the Head and Neck Cancer (HNC) in Indonesia is high (4,7/100.000). Cancer patients have high risk for weight loss and malnutrition, where nutritional status affects quality of life and comfortable feeling in cancer patients. Determining the nutritional status indicators can be used to predict the quality of life of patients with head and neck cancer. The study was observational with cross sectional design in Saiful Anwar Hospital, Malang in November 2010 - January 2011. Subjects were HNC patients that met inclusion criteria $(n=45)$. Nutritional status was determined with 3 methods, which are body mass index (BMI), subjective global assessment (SGA), and dietary intake assessment. Interview, weight and height measurement and physical examination were held to collect data. Chi square and linier regression analysis were used to get data analysis. There was a significant correlation between $S G A$ of category $A\left(\beta_{1}=30,631 ; p=0.001\right)$, intake of protein $\left(\beta_{2}=0,344 ; p=0.009\right)$, body mass index $\left(\beta_{3}=-1,533 ; p=0.028\right)$, and $S G A$ of category $B$ $\left(\beta_{4}=13,353 ; p=0.039\right)$ with quality of life of head and neck in cancer patients. Intake of energy was represented from intake of protein whereby both were mutually supportive. There was no correlation between intake of vitamin $A$ and quality of life $\left(\beta_{5}=0,000 ; p=0.907\right)$.The nutritional status can be used as a predictor for determining the quality of life scores of head and neck cancer patients, with the formula is: quality of life of HNC patients $=47.1+30.6$ (if SGAA) $+0.3($ protein intake $(\mathrm{g}))-1.5\left(B M I\left(\mathrm{~kg} / \mathrm{m}^{2}\right)\right)+13.3$ (if $\left.S G A B\right)$. Nutritional status was assessed by $B M I$, intake of protein, and SGA can be used to predict the quality of life scores in head and neck of cancer patients, where SGA is the most influential factor in determining the quality of life of patients with head and neck cancer.
\end{abstract}

Keywords: body mass index, intake of energy, protein, vitamin A, subjective global assessment, quality of life, head and neck cancer

\section{PENDAHULUAN}

Data dari World Health Organization (WHO) yang diterbitkan pada tahun 2007 menyebutkan bahwa sebanyak 7,6 juta jiwa meninggal pada 2005 dan 84 juta orang lainnya akan meninggal dalam jangka waktu 10 tahun ke depan, jika tidak ada tindakan nyata untuk menanggulangi penyakit kanker. Jumlah kasus kanker di Asia diperkirakan akan melonjak dari 4,5 juta pada 2002 menjadi 7,1 juta pada 2020. Di seluruh dunia diperkirakan terdapat 644.000 kasus baru kanker kepala dan leher, dimana dua pertiga dari kasus tersebut terjadi di negara berkembang. Pada tahun 2002 ditemukan 420.000 kasus baru kanker kepala dan leher pada pria dan 142.000 pada wanita di dunia. Di negara berkembang, insiden kanker tersebut lebih banyak terjadi pada laki-laki daripada perempuan dengan perbandingan 2 dibanding 1 , sementara di negara maju rasionya mencapai 3 dibanding 1[1].

Berdasarkan Riset Kesehatan Dasar (Riskesdas) tahun 2007, prevalensi tumor di Indonesia adalah 4,3 per 1000 penduduk. Prevalensi kanker kepala leher di Indonesia cukup tinggi yaitu menduduki urutan keempat dari seluruh keganasan yang terdapat pada pria dan wanita dan menempati urutan kedua dari seluruh keganasan yang terdapat pada pria. Selama 5 tahun (2001-2005) terdapat 448 kasus kanker kepala dan leher di RS Dr. Kariadi Semarang, dengan insiden tertinggi adalah kanker nasofaring (112 kasus atau 25\%) dan kanker kelejar getah bening leher (111 kasus atau 25\%) kemudian kanker tiroid 18\%, kanker rongga mulut $13 \%$, kanker cavum nasi dan sinus paranasalis $6 \%$, kanker maxilla dan mandibula $5 \%$, kanker laring $4 \%$, kanker parotis $2 \%$, dan kanker telinga $2 \%$ [2].

Masalah gizi merupakan masalah yang sering ditemui pada pasien kanker. Penurunan status gizi sering terjadi sebagai dampak dari penyakit kanker maupun terapinya [3]. Sebanyak $20 \%$ dari pasien kanker lebih banyak yang meninggal akibat keadaan gizi kurang daripada keganasan penyakitnya. Gizi kurang pada pasien kanker berakibat pada peningkatan biaya, termasuk waktu yang hilang karena tidak bisa bekerja, kelelahan, ketidakmampuan untuk 
beraktifitas normal dan status kesehatan yang semakin memburuk yang akan mengakibatkan kualitas hidup yang buruk [4].

Identifikasi dini dan pengkajian penurunan berat badan sangat penting untuk penanganan dini gizi kurang. Beberapa metode pengkajian status gizi termasuk pengukuran antropometri, biokimia, dan pengkajian fungsional digunakan untuk mengkategorikan tingkat masalah gizi yang terjadi. Pengkajian data klinis juga merupakan alat yang baik dan komponen-komponennya dapat diidentifikasi dan diformulasikan ke dalam suatu sistem pengkajian yang layak yaitu SGA (Subjective Global Assessment), yang sederhana dan mudah digunakan serta tervalidasi untuk mengklasifikasikan keadaan gizi kurang [5].

Asupan energi dan protein yang cukup sangat penting selama pengobatan kanker, pemulihan, dan harapan hidup yang panjang. Biasanya pasien dengan status performa fisik yang buruk mempunyai harapan hidup yang lebih pendek [6]. Sehingga status gizi pasien yang buruk dapat mempengaruhi status performa fisik setelah pengobatan kanker [7].

Survei secara epidemiologis menunjukkan bahwa defisiensi vitamin A dapat meningkatkan risiko kanker kepala dan leher [8]. Asupan beta karoten dari makanan yang rendah dan kadar beta karoten serum yang rendah berhubungan dengan peningkatan risiko keganasan berbagai macam sel epitel, termasuk salah satunya adalah kanker kepala dan leher [9].

Kualitas hidup merupakan salah satu luaran yang penting pada pasien kanker. Status gizi mempunyai efek terhadap kualitas hidup dan perasaan nyaman pada pasien kanker. Faktor spesifik seperti nyeri di mulut, suara serak, menghindari makan di tempat umum, bicara yang tidak jelas berkaitan dengan buruknya kualitas hidup pasien kanker [10].

Pengkajian kualitas hidup pasien dapat menggambarkan data mengenai persepsi pasien terhadap kesehatannya dan informasi tentang dampak gizi kurang dan dukungan gizi yang tepat untuk pasien. Skrining dan pengkajian status gizi penting untuk mengimplementasikan intervensi gizi secara dini sehingga dapat meningkatkan respon terapi atau pengobatan, status performa, dan kualitas hidup serta menurunkan morbiditas dan mortalitas pasien kanker. Pengkajian status gizi tidak hanya penting untuk pasien, dimana dukungan gizi dapat meningkatkan kualitas hidup [11].

\section{METODE PENELITIAN \\ Rancangan Penelitian}

Penelitian ini merupakan penelitian observasional dengan rancangan cross sectional, yaitu penelitian analitik yang memberikan informasi mengenai situasi yang ada dengan mengadakan observasi atau pengamatan antara status gizi (variabel bebas) dengan kualitas hidup pasien kanker kepala dan leher (variabel terikat) dilakukan pada waktu yang bersamaan. Penelitian dilakukan di Rumah Sakit Umum Dr. Saiful Anwar Malang. Penelitian ini dilaksanakan selama 3 bulan yaitu bulan November 2010 sampai Januari 2011. Penelitian ini telah memenuhi persyaratan etik sesuai dengan Keterangan Kelaikan Etik (Ethical Clearance) dengan Nomor: KE/FK/592/EC yang dinyatakan oleh Komisi Etik Penelitian Kedokteran dan Kesehatan Fakultas Kedokteran Universitas Gadjah Mada Yogyakarta.

\section{Sumber Data}

Populasi penelitian ini adalah semua pasien kanker kepala dan leher di RSU Dr. Saiful Anwar Malang dengan sampel yang memenuhi kriteria inklusi dan teknik pengambilan sampel adalah purposive sampling dan diperoleh 45 sampel. Kriteria inklusi sampel penelitian adalah pasien kanker kepala dan leher dengan jenis kelamin laki-laki atau perempuan yang datang ke RSU Dr. Saiful Anwar Malang baik yang menjalani rawat inap maupun rawat jalan, memiliki kesadaran compos mentis, dan tidak mengalami komplikasi penyakit kronik lain, yang diketahui dari data rekam medik pasien. Kriteria eksklusi yaitu apabila pasien tidak bersedia mengikuti penelitian.

\section{Teknik Pengumpulan Data}

Data karakteristik subjek terdiri dari identitas subjek dan data penunjang lain diambil melalui wawancara langsung dengan bantuan kuesioner. Data karakteristik subjek yang diambil meliputi: nama, alamat, jenis kelamin, 
usia, agama, pendidikan, pekerjaan, berat badan, tinggi badan, diagnosis penyakit, dan kebiasaan merokok. Data tentang asupan energi dan protein dikumpulkan melalui wawancara langsung dengan menggunakan formulir Food Recall, sedangkan asupan vitamin A dengan menggunakan formulir Semi Quantitative Food Frequency Questionnaire (SQFFQ) [12]. Untuk pemeriksaan status gizi sesuai dengan kondisi fisik/klinis sampel menggunakan formulir Subjective Global Assessment (SGA), dengan kategori: skor SGA A: gizi baik; SGA B: gizi kurang; SGA C: gizi buruk, sedangkan data tentang kualitas hidup diperoleh dengan cara wawancara dengan menggunakan kuesioner Short Form-36, yang sudah divalidasi ke dalam Bahasa Indonesia, dengan interpretasi kualitas hidup baik jika skor $\geq$ rata-rata skor kualitas hidup responden dan buruk jika skor <rata-rata skor kualitas hidup responden [13].

\section{Analisis Data}

Analisis asupan energi, protein, vitamin A diolah dengan menggunakan program nutri- survey. Penyajian data dengan analisis univariat untuk menampilkan data secara deskriptif yang meliputi: data jenis kelamin, usia, tingkat pendidikan, pekerjaan, status gizi, dan skoring kualitas hidup. Analisis bivariat untuk melihat hubungan antara dua variabel bebas dan variabel terikat. Analisis multivariat yaitu regresi logistik ganda untuk melihat hubungan yang paling berhubungan dari semua variabel bebas terhadap variabel terikat.

\section{HASIL PENELITIAN \\ Karakteristik Responden}

Berdasarkan Tabel 1 terlihat bahwa tidak terdapat hubungan yang signifikan antara karakteristik subjek dengan kualitas hidup pasien kanker kepala dan leher $(p>0,05)$. Hal tersebut dapat juga diartikan sebagai karakteristik responden yang meliputi jenis kelamin, umur, pendidikan, pekerjaan, dan riwayat merokok tidak berpotensi menjadi faktor pengganggu dalam penilaian terhadap kualitas hidup responden.

Tabel 1. Hubungan Karakteristik Subjek dengan Kualitas Hidup

\begin{tabular}{|c|c|c|c|c|c|c|c|c|c|}
\hline \multirow{3}{*}{ No } & \multirow{3}{*}{ Karakteristik } & \multicolumn{4}{|c|}{ Kualitas Hidup } & \multirow{2}{*}{\multicolumn{2}{|c|}{ Jumlah }} & \multirow{3}{*}{$p$} & \multirow{3}{*}{$\begin{array}{c}\text { RP } \\
(\mathbf{9 5 \%} \mathrm{CI})\end{array}$} \\
\hline & & \multicolumn{2}{|c|}{ Buruk } & \multicolumn{2}{|c|}{ Baik } & & & & \\
\hline & & $\mathbf{n}$ & $\%$ & $\mathbf{n}$ & $\%$ & $\mathbf{n}$ & $\%$ & & \\
\hline \multirow[t]{4}{*}{1.} & Jenis kelamin & & & & & & & \multirow{4}{*}{$1,000^{\mathrm{a}}$} & \multirow{4}{*}{$\begin{array}{c}0,83 \\
(0,164-4,239)\end{array}$} \\
\hline & - Laki-laki & 20 & 52,6 & 18 & 47,4 & 38 & 100 & & \\
\hline & - Perempuan & 4 & 57,1 & 3 & 42,9 & 7 & 100 & & \\
\hline & Jumlah & 24 & 53,3 & 21 & 46,7 & 45 & 100 & & \\
\hline \multirow[t]{4}{*}{2.} & Umur & & & & & & & \multirow{4}{*}{0,714} & \multirow{4}{*}{$\begin{array}{c}1,25 \\
(0,378-4,133)\end{array}$} \\
\hline & $-\leq 50$ tahun & 15 & 55,6 & 12 & 44,4 & 27 & 100 & & \\
\hline & $->50$ tahun & 9 & 50,0 & 9 & 50,0 & 18 & 100 & & \\
\hline & Jumlah & 24 & 53,3 & 21 & 46,7 & 45 & 100 & & \\
\hline \multirow[t]{4}{*}{3.} & Pendidikan & & & & & & & \multirow{4}{*}{$0,755^{\mathrm{a}}$} & \multirow{4}{*}{$\begin{array}{c}1,65 \\
(0,323-8,388)\end{array}$} \\
\hline & $\begin{array}{l}\text { - Dasar dan Lanjutan } \\
\text { (SD,SMP, SMA) }\end{array}$ & 21 & 55,3 & 17 & 44,7 & 38 & 100 & & \\
\hline & - Tinggi (diploma, sarjana) & 3 & 42,9 & 4 & 57,1 & 7 & 100 & & \\
\hline & Jumlah & 24 & 53,3 & 21 & 46,7 & 45 & 100 & & \\
\hline \multirow[t]{4}{*}{4.} & Pekerjaan & & & & & & & \multirow[b]{3}{*}{0,071} & \multirow[b]{3}{*}{$\begin{array}{c}3,20 \\
(0,886-11,855)\end{array}$} \\
\hline & - Petani, buruh, tukang becak & 12 & 70,6 & 5 & 29,4 & 17 & 100 & & \\
\hline & $\begin{array}{l}\text { - PNS, swasta, wiraswasta, } \\
\text { tidak bekerja }\end{array}$ & 12 & 42,9 & 16 & 57,1 & 28 & 100 & & \\
\hline & Jumlah & 24 & 53,3 & 21 & 46,7 & 45 & 100 & & \\
\hline \multirow[t]{4}{*}{5.} & Riwayat merokok & & & & & & & \multirow{4}{*}{0,731} & \multirow{4}{*}{$\begin{array}{c}1,25 \\
(0,351-4,458)\end{array}$} \\
\hline & - Pernah merokok & 16 & 51,6 & 15 & 48,4 & 31 & 100 & & \\
\hline & - Tidak pernah merokok & 8 & 57,1 & 6 & 42,9 & 14 & 100 & & \\
\hline & Jumlah & 24 & 53,3 & 21 & 46,7 & 45 & 100 & & \\
\hline
\end{tabular}

${ }^{a}$ Uji Fisher's exact 
Tabel 2 menunjukkan adanya hubungan yang bermakna antara asupan energi dan protein dengan kualitas hidup. Tidak ada hubungan antara IMT dan asupan vitamin A dengan kualitas hidup pasien kanker kepala dan leher ( $p>0,05)$. Namun bila dilihat dari skor kualitas hidup, subjek dengan IMT normal mempunyai skor kualitas hidup yang lebih baik dibanding dengan IMT kurang atau lebih yaitu dengan skor kualitas hidup rata-rata untuk IMT normal $(18,5-23,5$ $\left.\mathrm{kg} / \mathrm{m}^{2}\right)$ adalah 49,65 , IMT kurang $\left(<18,5 \mathrm{~kg} / \mathrm{m}^{2}\right)$ 42,04, dan IMT lebih $\left(>23,5 \mathrm{~kg} / \mathrm{m}^{2}\right) 41,08$.

\section{Tabel 2. Hubungan IMT, Asupan Energi, Protein, Vitamin A dengan Kualitas Hidup}

\begin{tabular}{llcc}
\hline \multicolumn{1}{c}{ Variabel Bebas } & Satuan & Koefisien Korelasi & \multicolumn{1}{c}{ P } \\
\hline IMT & $\mathrm{kg} / \mathrm{m}^{2}$ & 0,290 & 0,849 \\
Asupan energi & $\mathrm{kcal}$ & 0,420 & $0,004^{*}$ \\
Asupan protein & $\mathrm{g}$ & 0,353 & $0,017^{*}$ \\
Asupan vitamin A & $\mu \mathrm{g}$ & 0,094 & 0,311 \\
\hline
\end{tabular}

Tabel 3 menunjukkan bahwa ada hubungan yang bermakna antara SGA dengan kualitas hidup, yaitu kualitas hidup baik paling banyak dijumpai pada subjek dengan SGA kategori A dan $B$ daripada $C(p<0,05)$.

Tabel 3. Hubungan SGA dengan Kualitas Hidup

\begin{tabular}{|c|c|c|c|c|c|c|c|}
\hline \multirow{3}{*}{$\begin{array}{c}\text { Kategori } \\
\text { SGA }\end{array}$} & \multicolumn{4}{|c|}{ Kualitas hidup } & \multirow{2}{*}{\multicolumn{2}{|c|}{ Total }} & \multirow{3}{*}{$p$} \\
\hline & \multicolumn{2}{|c|}{ Buruk } & \multicolumn{2}{|c|}{ Baik } & & & \\
\hline & $\mathbf{n}$ & $\%$ & $\mathbf{n}$ & $\%$ & $\mathbf{n}$ & $\%$ & \\
\hline SGA C & 9 & 81,8 & 2 & 18,2 & 11 & 100 & \\
\hline SGA A, B & 15 & 44,1 & 19 & 55,9 & 34 & 100 & $0,029 *$ \\
\hline Jumlah & 24 & 53,3 & 21 & 46,7 & 45 & 100 & \\
\hline
\end{tabular}

Pada analisis multivariat dengan regresi linier ganda didapatkan hasil bahwa SGA kategori A mempunyai hubungan yang paling kuat atau paling mempengaruhi skor kualitas hidup pasien kanker kepala dan leher. Dari Tabel 4 dapat disusun formula untuk mengetahui skor kualitas hidup pasien kanker kepala dan leher, yaitu: kualitas hidup pasien $\mathrm{KKL}=47,1+30,6$ (jika SGA A) $+0,3$ (asupan protein $(\mathrm{g})$ ) $-1,5$ (IMT $\left.\left(\mathrm{kg} / \mathrm{m}^{2}\right)\right)+13,3($ jika SGA B).

Tabel 4. Analisis Multivariat

\begin{tabular}{|c|c|c|c|}
\hline & Koefisien ( $\beta$ ) & SE & $p$ \\
\hline Konstanta & 47,086 & 12,176 & $0,000^{*}$ \\
\hline SGA Kategori A & 30,631 & 8,580 & $0,001 *$ \\
\hline Protein & 0,344 & 0,124 & $0,009 *$ \\
\hline IMT & $-1,533$ & 0,670 & $0,028 *$ \\
\hline SGA Kategori $\mathrm{E}$ & 13,354 & 6,240 & $0,039 *$ \\
\hline Vitamin A & 0,000 & 0,002 & 0,907 \\
\hline
\end{tabular}




\section{PEMBAHASAN}

Pada penelitian ini didapatkan hasil bahwa pasien laki-laki lebih banyak daripada perempuan. Penelitian lain menyatakan bahwa rasio pasien kanker kepala dan leher laki-laki dibanding perempuan adalah 3-4 dibanding 1 [1].

Kebanyakan responden berada dalam kelompok usia 41-50 tahun yaitu sebanyak 31,5\% dan sebagian besar responden memiliki riwayat pernah merokok (68,9\%). Penelitian lain menyebutkan bahwa insiden kanker kepala dan leher meningkat seiring dengan bertambahnya usia, terutama di atas usia 50 tahun. Meskipun sebagian besar pasien berusia antara 50-70 tahun, tetapi kanker kepala dan leher dapat diderita oleh pasien pada kelompok umur yang lebih muda [11].

Secara umum, jenis kelamin tidak berhubungan dengan kualitas hidup pasien kanker kepala dan leher $(\mathrm{p}=0,826)$. Tidak ada hubungan yang signifikan antara jenis kelamin dengan kecacatan (salah satu indikator kualitas hidup), yang dalam hal ini juga kecacatan dapat mencerminkan tingkat kualitas hidup dan status fungsional seseorang [13]. Penelitian lain menyatakan bahwa tidak ada hubungan antara jenis kelamin dan kualitas hidup $(\mathrm{p}=0,08)$ [14]. Namun pada penelitian lain menunjukkan bahwa pasien perempuan mempunyai skor kualitas hidup yang lebih baik daripada laki-laki, di mana menggunakan instrumen kuesioner kualitas hidup yang berbeda. Selain itu, adanya perbedaan kualitas hidup berdasarkan jenis kelamin juga tergantung pada jenjang pekerjaan/karir dan produktivitas ekonominya [15].

Ditinjau dari riwayat merokok, dalam penelitian ini didapatkan hasil bahwa tidak ada hubungan antara riwayat merokok dengan kualitas hidup pasien kanker kepala dan leher. Penelitian lain menyatakan bahwa ada hubungan kausatif antara merokok dan kualitas hidup, yaitu adanya efek dari berhenti merokok. Pasien yang tetap merokok setelah diagnosis dan pengobatan mempunyai skor kualitas hidup yang lebih buruk dibandingkan dengan yang berhenti merokok atau tidak pernah merokok [16]. Pada penelitian ini, tidak dibedakan antara sampel yang mempunyai riwayat merokok, masih merokok atau berapa lama sampel tersebut terpapar oleh rokok sehingga sulit menjelaskan bagaimana hubungan paparan rokok dengan kanker kepala dan leher.

Apabila dianalisis multivariat, IMT berhubungan dengan kualitas hidup dengan tingkat signifikansi 0,011 . IMT berhubungan dengan fungsi fisik yang buruk dan tingkat kecacatan yang tinggi [17]. Pasien kanker payudara, prostat, colorectal, rahim, dan kulit dengan berat badan normal maupun lebih (overweight) mempunyai fungsi fisik dan kesehatan mental yang lebih baik dibandingkan dengan yang obese. IMT dan aktivitas fisik juga berhubungan dengan kualitas hidup yang juga tergantung dari jenis kanker sehingga IMT dan aktivitas fisik dapat digunakan untuk membantu memperbaiki efek samping kanker dan meningkatkan kualitas hidup [18]. Pada populasi orang Asia, subjek dengan status gizi kurang (underweight) mempunyai skor kualitas hidup yang lebih buruk dibandingkan dengan subjek yang mempunyai berat badan normal, pre-obese, dan obese. Hal tersebut dapat tergantung dari penggunaan cut-off IMT [19]. IMT tidak berdiri sendiri sebagai faktor utama yang berperan dalam menentukan kualitas hidup pasien kanker kepala dan leher. Hal tersebut akan lebih jelas apabila dikombinasikan dengan variabel lainnya, misalnya asupan energi, protein, vitamin A maupun status gizinya yang dilihat dari SGA.

Dari hasil penelitian di atas dapat diketahui bahwa status gizi berdasarkan kondisi fisik seseorang yang dinilai dengan SGA mempunyai hubungan yang signifikan dengan kualitas hidup pasien kanker kepala dan leher $(\mathrm{p}=0,000$ untuk pasien dengan skor SGA A dan $p=0,013$ untuk pasien dengan skor SGA B). Skor SGA berhubungan dengan persentase penurunan berat badan dan IMT yang dapat digunakan untuk mengukur tingkat morbiditas (harapan hidup dan lama rawat) dengan tingkat sensitifitas dan spesifisitas yang tinggi. Skor SGA dapat digunakan sebagai alat pengkajian gizi yang dapat mengidentifikasi gizi kurang atau gizi buruk pada pasien rawat jalan untuk merencanakan dukungan gizi yang tepat. Selain itu juga dapat digunakan untuk mengukur hasil intervensi gizi dan berhubungan dengan kualitas hidup pasien kanker kepala dan leher yang menerima radioterapi sehingga perubahan skor SGA dapat digunakan untuk memprediksi arah dan besarnya perubahan kualitas hidup [20].

Asupan energi dan protein berhubungan secara signifikan dengan kualitas hidup pasien kanker kepala dan leher dengan nilai $\mathrm{p}<0,05$. Pada tingkat asupan energi dan protein yang rendah, skor kualitas hidup juga lebih rendah daripada sampel dengan asupan energi dan protein cukup. Secara analisis multivariat, hubungan asupan energi dan kualitas hidup diperkuat oleh asupan protein. Jika asupan protein tinggi, maka asupan energinya pun akan mengikutinya. Penurunan status gizi yang dikombinasikan dengan defisiensi zat gizi menjadi faktor yang lebih penting dalam memprediksi kualitas 
hidup pasien kanker. Penurunan cadangan zat gizi dapat mempengaruhi sistem imun, tingkat kesenangan/kebahagiaan, dan interaksi sosial dengan teman maupun keluarga, dimana hal tersebut dapat menekan nafsu makan [21].

Dari hasil penelitian diketahui bahwa tidak ada hubungan antara asupan vitamin A dengan kualitas hidup pasien kanker kepala dan leher. Peran retinoid adalah menurunkan resiko perkembangan kanker sel squamous melalui penekanan proses karsinogenesis dan menghambat perkembangan tumor primer dan sekunder. Hal tersebut lebih sering terjadi pada pasien kanker dengan stadium awal. Tetapi kebanyakan pasien kanker terdiagnosa dalam stadium lanjut karena pada stadium awal tanda dan gejala kanker kurang nampak sehingga sulit membuktikan hubungan vitamin A dengan progresivitas penyakitnya yang bisa berpengaruh terhadap kualitas hidupnya [22].

Vitamin A berperan sebagai agen kemopreventif yang dapat menghambat progresifitas dari sel kanker sehingga pasien yang sudah terdiagnosa kanker stadium awal, bila kebutuhan vitamin A dapat terpenuhi maka perkembangan penyakitnya dapat terhambat atau tidak berkembang menjadi kanker stadium lanjut sehingga kualitas hidupnya pun dapat dipertahankan dalam kondisi yang baik [8]. Dalam penelitian ini, tidak dibedakan stadium kankernya sehingga sulit mendeteksi bagaimana peran vitamin A sebagai agen kemopreventif terutama pada stadium awal yang kemudian dihubungkan dengan tingkat kualitas hidupnya.

\section{KESIMPULAN}

Dari penelitian yang telah dilakukan dapat diambil kesimpulan yaitu terdapat hubungan yang bermakna antara status gizi berdasarkan antropometri (IMT), pemeriksaan fisik/klinis (SGA), asupan zat gizi (energi dan protein) dengan kualitas hidup pasien kanker kepala dan leher. Tetapi tidak ada hubungan antara asupan vitamin A dengan kualitas hidup pasien kanker kepala dan leher. Ada perbedaan kekuatan/ kemampuan dari berbagai macam indikator status gizi sebagai prediktor kualitas hidup pada kanker kepala dan leher, di mana SGA merupakan faktor yang paling berpengaruh dalam menentukan kualitas hidup pasien kanker kepala dan leher.

\section{SARAN}

Untuk penelitian selanjutnya membedakan stadium, lokasi kanker secara spesifik, dan terapi yang dilakukan secara lebih mendetail dengan mengambil jumlah sampel yang lebih besar. Dan perlunya skrining gizi dan penilaian status gizi karena status gizi sangat berperan dalam menentukan kualitas hidup pasien kanker kepala dan leher.

\section{DAFTAR RUJUKAN}

1. Brown LM, Gridley G, dan Devesa SS. Descriptive Epidemiology: U.S. Patterns. In: Epidemiology, Pathogenesis, and Prevention of Head and Neck Cancer ed. Olshan A.F. USA:Springer Science + Business Media, LLC 2010; 23-39.

2. Wiliyanto O. Insidensi Kanker Kepala dan Leher Berdasarkan Diagnosis Patologi Anatomi di RS Kariadi Semarang Periode 1 Januari 2001-31 Desember 2005. [Artikel Penelitian]. Semarang: Fakultas Kedokteran Universitas Diponegoro; 2005.

3. Capra S, Ferguson M, dan Ried K. Cancer: Impact of Nutrition Intervention OutcomeNutrition Issues for Patients. Nutrition 2001: 17; $769-72$.

4. Nourissat A, Vasson MP, Merrouche Y, Bouteloup C, Goutte M, Mille D, Jacquin JP, Collard O, Michaud P, dan Chauyin F. Relationship between nutritional status and quality of life in patients with cancer. European Journal of Cancer 2008; 1238-42.

5. Nursal TZ, Noyan T, Tarim A, dan Karakayali H. A New weighted scoring system for Subjective Global Assessment. Nutrition 2005: 21; 666-71.

6. Tian J, Chen ZC, dan Hang LF. Effects of nutritional and psychological status in gastrointestinal cancer patients on tolerance of treatment. World J Gastroenterol 2007. August; 13(30): 4136-40.

7. Doyle C, Kushi LH, Byers T, Courneya KS, Wahnerfried WD, Grant B, McTiernan A, Rock CL, Thompson C, Gansler T, dan Andrews KS. Nutrition and Physical Activity During and After Cancer Treatment: An American Cancer Society Guide for Informed Choices. CA Cancer J Clin 2006; 56: 323-53.

8. Vidaurre C, Sebastian B, Gavalda C, Cifuentes C. Retinoids: application in premalignant lesions and oral cancer. Med Oral 2001 Mar-Apr; 6(2):11423.

9. Girod SC dan Pfahl M. Retinoid actions and implications for prevention and therapy of oral cancer. Int. J. Oral Maxillofac Surg 1996; 25: 6973. 
10. Huhmann MB dan Cunningham RC. Importance of nutritional screening in treatment of cancerrelated weight loss. Lancet Oncol 2005; 6: 33443.

11. Davies M. Nutritional screening and assessment in cancer-associated malnutrition. European Journal of Oncology Nursing 2005; 9: S64-73.

12. Gibson R. Principle of Nutritional Assesment. New York: Oxford University Press; 2006.

13. Rahmawan A. Kualitas hidup penderita karsinoma nasofarings pascaterapi; perbandingan antara yang mendapat radioterapi dengan kombinasi radioterapi ditambah kemoterapi. Karya Akhir, Bagian Ilmu Penyakit Telinga Hidung dan Tenggorok. Yogyakarta: Universitas Gadjah Mada; 2006.

14. Taylor JC, Terrell JE, Ronis DL, Fowler KE, Bishop C, Lambert MT, Myers LL, dan Duffy SA. Disability in Patients With Head and Neck Cancer. Arch Otolaryngol Head Neck Surg 2004 June; 130:764-9.

15. Onakoya PA, Nwaorgu OG, Adenipekun AO, Aluko AA, dan Ibekwe TS. Quality of Life in Patients with Head and Neck Cancers. J NatI Med Assoc 2006; 98(5):765-70.

16. Jensen K, Jensen AB, dan Grau C. Smoking has a negative impact upon health related quality of life after treatment for head and neck cancer. J oraloncology 2006 July; 43: 187-92.

17. Caldwell J, Johnson TH, dan Green CR. Body Mass Index and Quality of Life: Examining Blacks and Whites With Chronic Pain. The Journal of Pain 2009 January: 10(1): 60-7.

18. Blanchard CM, Stein K, dan Courneya KS. Body mass index, physical activity, and health-related quality of life in cancer survivors. Med Sci Sports Exer 2010 Apr; 42(4):665-71.

19. Wee HL, Cheung YB, Loke WC, Tan CB, Chow MH, Li SC, Fong KY, Feeny D, Machin D, Luo N, dan Thumboo J. The Association of Body Mass Index with Health-Related Quality of Life: An Exploratory Study in a Multiethnic Asian Population. Value in Health 2008; 11(1): 105-14.

20. Bauer J, Capra S, dan Ferguson M. Use of the scored Patient-Generated Subjective Global Assessment (PG-SGA) as a nutrition assessment tool in patients with cancer. European Journal of Clinical Nutrition 2002; 56: 779-85.

21. Tian J dan Chen JS. Nutritional status and quality of life of the gastric cancer patients in Changle County of China. World J Gastroenterol 2005 March; 11(11):1582-6.
22. Ridge JA, Glisson BS, Horwitz EM, dan Meyers MO. Head and Neck Tumors. Cancer Management: A Multidisciplinary Approach; 2003. 